Check for updates

Cite this: RSC Adv., 2019, 9, 5064

\title{
Parameter optimization and degradation mechanism for electrocatalytic degradation of 2,4- diclorophenoxyacetic acid (2,4-D) herbicide by lead dioxide electrodes $\uparrow$
}

\author{
Abdollah Dargahi, (DD a Amin Ansari, ${ }^{\text {b }}$ Davood Nematollahi, ${ }^{\mathrm{b}}$ Ghorban Asgari, ${ }^{\mathrm{a}}$ \\ Reza Shokoohi ${ }^{a}$ and Mohammad Reza Samarghandi*c
}

2,4-Dichlorophenoxyacetic acid (2,4-D) is one of the most commonly used herbicides in the world. In this work, the electro-catalytic degradation of 2,4-D herbicide from aqueous solutions was evaluated using three anode electrodes, i.e., lead dioxide coated on stainless steel $316\left(\mathrm{SS} 316 / \beta-\mathrm{PbO}_{2}\right)$, lead dioxide coated on a lead bed $\left(\mathrm{Pb} / \beta-\mathrm{PbO}_{2}\right)$, and lead dioxide coated on graphite $\left(\mathrm{G} / \beta-\mathrm{PbO}_{2}\right)$. The structure and morphology of the prepared electrodes were studied by $X$-ray diffraction (XRD), scanning electron microscopy (SEM) and energy dispersive X-ray spectroscopy (EDX). The process of herbicide degradation was monitored during constant current electrolysis using cyclic voltammetry (CV). In this study, the experiments were designed based on the central composite design (CCD) and were analyzed and modeled by response surface methodology (RSM) to demonstrate the operational variables and the interactive effect of three independent variables on 3 responses. The effects of parameters including $\mathrm{pH}$ (3-11), current density $\left(j=1-5 \mathrm{~mA} \mathrm{~cm}^{-2}\right)$ and electrolysis time (20-80 min) were studied. The results showed that, at $j=5 \mathrm{~mA} \mathrm{~cm}{ }^{-2}$, by increasing the reaction time from 20 to $80 \mathrm{~min}$ and decreasing the $\mathrm{pH}$ from 11 to 3, the 2,4-D herbicide degradation efficiency using $\mathrm{SS} 316 / \beta-\mathrm{PbO}_{2}, \mathrm{~Pb} / \beta-\mathrm{PbO}{ }_{2}$ and $\mathrm{G} / \beta$ $\mathrm{PbO}_{2}$ anode electrodes was observed to be $60.4,75.9$ and $89.8 \%$, respectively. Moreover, the results showed that the highest $\mathrm{COD}$ and TOC removal efficiencies using the $\mathrm{G} / \beta-\mathrm{PbO}_{2}$ electrode were 83.7 and $78.5 \%$, under the conditions $\mathrm{pH}=3$, electrolysis time $=80 \mathrm{~min}$ and $j=5 \mathrm{~mA} \mathrm{~cm}^{-2}$, respectively. It was also found that $\mathrm{G} / \beta-\mathrm{PbO}_{2}$ has lower energy consumption (EC) (5.67 $\mathrm{kW} \mathrm{h} \mathrm{m}{ }^{-3}$ ) compared to the two other studied electrodes $\left(\mathrm{SS} 316 / \beta-\mathrm{PbO}_{2}\right.$ and $\left.\mathrm{Pb} / \beta-\mathrm{PbO}_{2}\right)$. The results showed a good correlation between the experimental values and the predicted values of the quadratic model $(P<0.05)$. Results revealed that the electrochemical process using the $\mathrm{G} / \beta-\mathrm{PbO}_{2}$ anode electrode has an acceptable efficiency in the degradation of 2,4-D herbicide and can be used as a proper pretreatment technique to treat wastewater containing resistant pollutants, e.g., phenoxy group herbicides (2,4-D).

Received 9th December 2018 Accepted 4th February 2019

DOI: $10.1039 / c 8 r a 10105 a$

rsc.li/rsc-advances contribute to releasing these toxins into the surface water resources and soil before degradation. ${ }^{\mathbf{1}}$ Pesticides are classified into herbicides, insecticides, fungicides, bactericides, acaricides, and rodenticides according to their purpose, method and period of use or chemical properties. ${ }^{2}$ The chlorinated phenoxy acids herbicides are considerably used in agriculture against the growth of broadleaf weeds in rice, wheat, and corn. ${ }^{3,4}$

2,4-Dichlorophenoxyacetic acid $(2,4-\mathrm{D})$ is a herbicide, which is extensively used around the world. The excellent properties including the low cost and the high efficiency to control the broadleaf weeds in a variety of settings such as crops, rights-ofway, lawns and forests have introduced the 2,4-D as the most commonly used herbicides. ${ }^{5-7}$

Degradation of 2,4-D is very slow in water; its half-life in water range from one to several weeks under aerobic conditions, while it can be more than 120 days under anaerobic
University of Medical Sciences, Hamadan, Iran

${ }^{b}$ Department of Chemistry, Faculty of Chemistry, Bu-Ali-Sina University, Hamadan, Iran

${ }^{c}$ Department of Environmental Engineering School of Public Health, Hamadan University of Medical Sciences, Hamadan, Iran.E-mail: samarghandi@umsha.ac.ir

$\dagger$ Electronic supplementary information (ESI) available. See DOI: 10.1039/c8ra10105a 
conditions. ${ }^{8}$ The International Agency for Research on Cancer of the World Health Organization categorized this herbicide as "possibly carcinogenic to humans, according to insufficient evidence in humans and limited evidence in experimental animals". 9 The issues associated with the exposure to this herbicide have been studied in different applicators, but the risk of 2,4-D to human health has not thoroughly assessed. ${ }^{\mathbf{1 0}}$ The results of the previous studies clarified that the consumption of 2,4-D by laboratory animals has resulted in the objectionable effects on eyes, thyroid, kidneys, adrenal glands, ovaries and testicles. ${ }^{\mathbf{1 1}}$ It is also observed that the utilization of this herbicide is associated with teratogenic, genotoxic, neurotoxic, immune suppressant and cytotoxic effects. ${ }^{112}$ The extensive use and poor biodegradability of 2,4-D are led to its ubiquitous presence in the environment, which is led to the contamination of surface and ground waters. ${ }^{13}$ Hereupon, the attempts have vastly implemented to eliminate this herbicide through the different techniques such as adsorption, ${ }^{\mathbf{1 4 , 1 5}}$ biological decomposition ${ }^{\mathbf{8 1 6 , 1 7}}$ and plasma-ozonation. ${ }^{9}$ However, these techniques have serious disadvantages and issues, e.g., high cost, incomplete pollutant removal, production of toxic byproducts, need to add the chemical compounds, sludge production and need for more treatment. ${ }^{18}$

Over the last two decades, the electrochemical technologies, due to their high efficiency, environmentally friendly and versatility have provided great developments in wastewater treatment, especially for the elimination of the bio-refractory substances. ${ }^{19}$ Since the electrochemical advanced oxidation processes (EAOPs) are not involved in the toxic reagents and the electron is considered as their main reagents, they account for as the eco-friendly emergent techniques for water remediation. ${ }^{20}$ The degradation process is performed by the direct reaction of organics at the anode surface by charge transfer, whereas the degradation of pollutants, at high current, is preferentially carried out due to the oxidation of the pollutants by the oxidizing agents produced at the anode. ${ }^{21,22}$ The anodic oxidation or electrochemical oxidation (EO) is the most convenient and common EAOP, in which the physisorbed $\mathrm{M}(\cdot \mathrm{OH})$ radical produced by water oxidation degrades the organics in this technique. ${ }^{21}$ The anodes, which have incredible potential for the oxygen evolution reaction (OER) and are capable to generate the weakly adsorbed hydroxyl radicals, are considered as the brilliant anodes for electro-oxidation of organic compounds. ${ }^{23}$ Hence, the anodes such as boron-doped diamond (BDD), $\mathrm{SnO}_{2}-\mathrm{Sb}$, $\mathrm{IrO}_{2}$, and $\mathrm{PbO}_{2}$ have emerged as the most talented anodes for organic degradation. ${ }^{24,25}$ However, although the BDD electrode is chemically stable and shows the excellent ability in the degradation of the organics, it is still very expensive. ${ }^{26}$ The $\mathrm{SnO}_{2}-\mathrm{Sb}$ electrode is much less expensive, but it is deactivated after a short period of use. ${ }^{27}$ On the other hand, although $\mathrm{PbO}_{2}$ anodes show the lower electrochemical activity in the degradation of organics, compared to BDD and Sb-doped $\mathrm{SnO}_{2}$ electrodes, they offer the advantages including the easier production by electrodeposition, low electrical resistivity, and good electrochemical activity. Moreover, their stability was observed to be remarkable at high potentials and at different $\mathrm{pH}$ values. $^{28,29}$
In the present study, three anode electrodes, i.e., lead dioxide coated on stainless steel $316\left(\mathrm{SS} 316 / \beta-\mathrm{PbO}_{2}\right)$, lead dioxide coated on the lead bed $\left(\mathrm{Pb} / \beta-\mathrm{PbO}_{2}\right)$, lead dioxide coated on graphite $\left(\mathrm{G} / \beta-\mathrm{PbO}_{2}\right)$ were employed to study the degradation of 2-4-D herbicide from aqueous solutions. The experiments were designed based on central composite design (CCD) and were analyzed using the response surface methodology (RSM), which it provides proper statistical tools to design and to optimize the studied process. Morphology of prepared electrodes is characterized by scanning electron microscopy (SEM) coupled with energy dispersive X-ray spectroscopy (EDX) and X-ray diffraction (XRD). The process of herbicide degradation was monitored during constant current electrolysis using cyclic voltammograms (CV) techniques. After the electrolysis process and complete degradation of 2,4-D herbicide, the leaching of lead ions and the mechanism of 2,4-D degradation were evaluated.

\section{Materials and methods}

All parts of materials and methods section including materials, analytical method, electrochemical treatments, preparation of the $\mathrm{SS} 316 / \beta-\mathrm{PbO}_{2}$ electrode, preparation of the $\mathrm{Pb} / \beta-\mathrm{PbO}_{2}$ electrode, preparation of the $\mathrm{G} / \beta-\mathrm{PbO}_{2}$ electrode and experimental design, can be found at ESI. $\dagger$

\section{Results and discussion}

\subsection{Characterization of $\beta-\mathrm{PbO}_{2}$ electrodes}

The SEM technique was applied to evaluate the surface morphology of $\mathrm{PbO}_{2}$ electrodeposited on graphite, lead and stainless steel 316 (SS316) substrate and the results, under four different views $(50,20,10$ and $5 \mu \mathrm{m})$, were represented in Fig. S3 (Part I, a-c).† All particles revealed an agglomeration with limited individual particle boundary. The results of these images revealed the crystalline structures of $\beta-\mathrm{PbO}_{2}$ in the electrodeposited $\mathrm{PbO}_{2}$ microparticles on graphite, lead and SS316 and also clarified that the $\beta-\mathrm{PbO}_{2}$ has the tetragonal structure.

Elemental analysis of the $\beta-\mathrm{PbO}_{2}$ was performed using Energy-dispersive X-rays (EDX) technique and results were presented in Fig. S3 (Part II). $\dagger$ As shown in Fig. S3 (Part II), $\dagger$ the weight percentage of oxygen $(\mathrm{O})$ and lead $(\mathrm{Pb})$, the main elements existed in the $\beta-\mathrm{PbO}_{2}$, were $20.9 \%, 79.1 \%$ for graphite electrode and $19.5 \%, 80.5 \%$ for $\mathrm{Pb}$ electrode and $20.1 \%, 79.9 \%$ for SS316, respectively.

X-ray diffraction patterns (XRD) measurements were used to estimate the phases and crystallinity of $\mathrm{PbO}_{2}$ and the deposited film. Fig. S3 (Part III $\dagger$ ) is related to the XRD of the $\mathrm{PbO}_{2}$ layer deposited on the graphite, lead and SS316 interlayers in which the diffraction peaks of the $\beta$ form of $\mathrm{PbO}_{2}$ has represented. All XRD results show the tetragonal structure of $\beta-\mathrm{PbO}_{2}$. Unlike the orthorhombic $\alpha-\mathrm{PbO}_{2}$, the tetragonal $\beta-\mathrm{PbO}_{2}$ is characterized by favorable conductivity, ${ }^{38,42}$ which can exceptionally assist the anode employed in electro-oxidation of contaminants in aqueous solution. The main peaks, which it is observed at $2 \theta$ of $25.4^{\circ}, 32.0^{\circ}, 36.2^{\circ}, 49.1^{\circ}, 53.5^{\circ}, 58.7^{\circ}, 62.5^{\circ}$ and $75.4^{\circ}$ for these three electrodes (graphite, lead and SS316), are corresponded to 
Table 1 Experimental conditions for measuring the efficiency of an electrochemical process for 2,4-diclorophenoxy acetic acid herbicide degradation

\begin{tabular}{|c|c|c|c|c|c|c|}
\hline Run & A: $\mathrm{pH}$ & $\begin{array}{l}\mathrm{B}: j(\mathrm{~mA} \\
\left.\mathrm{cm}^{-2}\right)\end{array}$ & $\mathrm{C}:$ time (min) & \multicolumn{3}{|c|}{ 2,4-D herbicide removal efficiency (\%) } \\
\hline 2 & 7 & 3 & 50 & 33.94 & 50.89 & 65.34 \\
\hline 3 & 7 & 3 & 50 & 34.5 & 55.1 & 68.3 \\
\hline 4 & 3 & 3 & 50 & 39.15 & 59.87 & 74.99 \\
\hline 7 & 7 & 1 & 50 & 28.72 & 48.25 & 60.56 \\
\hline 8 & 11 & 5 & 20 & 18.53 & 28.74 & 44.5 \\
\hline 9 & 7 & 3 & 50 & 30.86 & 48.5 & 61.5 \\
\hline 10 & 3 & 5 & 80 & 60.46 & 75.93 & 89.88 \\
\hline 11 & 7 & 5 & 50 & 47.27 & 64.03 & 78.29 \\
\hline 12 & 3 & 1 & 20 & 14.84 & 28.71 & 44.71 \\
\hline 17 & 7 & 3 & 50 & 29.9 & 46.83 & 66.9 \\
\hline 18 & 3 & 5 & 20 & 23.23 & 33.91 & 47.66 \\
\hline 19 & 7 & 3 & 50 & 34.21 & 52.4 & 62.99 \\
\hline 20 & 11 & 1 & 20 & 10.68 & 18.75 & 33.94 \\
\hline
\end{tabular}

the (110), (101), (200), (211), (220), (310), (301) and (321) plane of $\beta-\mathrm{PbO}_{2}$, respectively. ${ }^{32,39}$ It is important to note that the existence of $\beta-\mathrm{PbO}_{2}$ in all samples was proven. In order to calculate the average size of $\beta-\mathrm{PbO}_{2}$, Debye-Scherrer formula was applied; $;^{32}$ based on the results obtained from this formula, the size of $\beta-\mathrm{PbO}_{2}$ crystals in the $\mathrm{G} / \beta-\mathrm{PbO}_{2}, \mathrm{SS} 316 / \beta-\mathrm{PbO}_{2}$ and $\mathrm{Pb} / \beta-$ $\mathrm{PbO}_{2}$ electrodes was obtained to be $30.2,44.7$, and $36.0 \mathrm{~nm}$, respectively. These results are consistent with the SEM results.

\subsection{Statistical analysis and the model fitting}

In this study, the central composite design (CCD) model was used to evaluate the interactive effect of parameters for optimizing the degradation of 2,4-D herbicide from aqueous solutions using modified electrode anodes. There were a total of 20 experiments (including 7 variable points, 7 axis points, 1 central point and 5 repetitive points in the center) for optimizing the variables in the CCD statistical design (Table 1). The model was found to be reasonable for predictions made within the range of experimental variables. The models expressed in Table 2, where the variables take their coded values, represent the 2,4-D herbicide degradation efficiency using three anodes electrodes of $\mathrm{SS} 316 / \beta-\mathrm{PbO}_{2}, \mathrm{~Pb} / \beta-\mathrm{PbO}_{2}$ and $\mathrm{G} / \beta-\mathrm{PbO}_{2}\left(Y_{1}, Y_{2}\right.$ and $\left.Y_{3}\right)$ as a function of $\mathrm{pH}(\mathrm{A})$, current density (B) and electrolysis time (C). The models are obtained after rectifying the ineffective variables and interacting with them. The suitability of the models is determined by the correlation coefficient $R^{2}$ and adjusted $R^{2}$. The $R^{2}$ coefficient is specified as the ratio of the described variable to the total variation and the degree of fitness of the model, which it was reasonably found to be high in all models $\left(R^{2}=0.953-0.956\right)$. The values greater than 4 for the accuracy and validity of the model is indicative of its desirability; $;^{35,36}$ as can be observed, these values were obtained to be in the range of 25.54-27.09 for all responses. Furthermore, the values of standard deviation (3.06-3.75) and coefficient of variation (CV) (5.82-9.89) illustrate the significance and the high reliability of results. It should be mentioned that the extent and direction of the effect of independent parameters on the efficiency of the electrochemical process are identified by the coefficients of these equations and their mathematical symbols $( \pm)$ (Table 2). Also, based on statistical analyses, the models

Table 2 Summary of model for three anodes electrodes $\mathrm{SS} 316 / \beta-\mathrm{PbO}_{2}, \mathrm{~Pb} / \beta-\mathrm{PbO}$ and $\mathrm{G} / \beta-\mathrm{PbO} 2$

\begin{tabular}{|c|c|c|c|c|c|c|c|c|}
\hline$Y_{1}$ & $\begin{array}{l}+34.33-6.33 \mathrm{~A}+7.47 \mathrm{~B}+10.76 \mathrm{C}-4.41 \mathrm{AC} \\
+2.85 \mathrm{BC}-6.67 \mathrm{C} 2\end{array}$ & Quadratic & 0.954 & 0.933 & 27.09 & 3.06 & 9.89 & 369.83 \\
\hline$Y_{2}$ & $\begin{array}{l}+52.11-8.12 \mathrm{~A}+7.71 \mathrm{~B}+12.52 \mathrm{C}-4.48 \mathrm{AC} \\
+3.87 \mathrm{BC}-11.18 \mathrm{C} 2\end{array}$ & Quadratic & 0.953 & 0.931 & 25.54 & 3.75 & 8.07 & 425.49 \\
\hline$Y_{3}$ & $\begin{array}{l}+66.14-8.31 \mathrm{~A}+7.13 \mathrm{~B}+12.29 \mathrm{C}-4.77 \mathrm{AC} \\
+3.33 \mathrm{BC}-10.56 \mathrm{C} 2\end{array}$ & Quadratic & 0.956 & 0.935 & 26.49 & 3.54 & 5.82 & 466.52 \\
\hline
\end{tabular}


have low probability values and high reliability levels. The low values of variance coefficients are indicative of the suitable accuracy and superior reliability of data. The $P$ values for the studied responses were 0.0001 . The higher values of $\mathrm{F}$ and fewer values of $P$ demonstrate the meaningfulness of the models and all of the studied factors were found to be significant ( $P$ value $<$ 0.05). The lack-of-fit $F$-test describes the variation of the data around the fitted model. According to Tables S2-S4, $\dagger$ the lack of fit (LOF) $P$ values of $>0.05$ was obtained to be statistically insignificant for 2,4-D herbicide degradation using three anodes electrodes ( $\mathrm{SS} 316 / \beta-\mathrm{PbO}_{2}, \mathrm{~Pb} / \beta-\mathrm{PbO}_{2}$ and $\mathrm{G} / \beta-\mathrm{PbO}_{2}$ ), implying a correlation between the variables and 2,4-D herbicide degradation. Residuals plots, which define the difference between the observed values of a response and its predicted value, are important for determining the competence of the model. Normal test plots are graphical tools for signifying the residuals departure from a straight line. The normal probability plot of 2,4-D herbicide degradation using three anodes electrodes of $\mathrm{SS} 316 / \beta-\mathrm{PbO}_{2}, \mathrm{~Pb} / \beta-\mathrm{PbO}_{2}$ and $\mathrm{G} / \beta-\mathrm{PbO}_{2}$ (Fig. $1\left(\mathrm{a}_{1}, \mathrm{~b}_{1}\right.$ and $\left.c_{1}\right)$ ) show that almost all data points are normally scattered

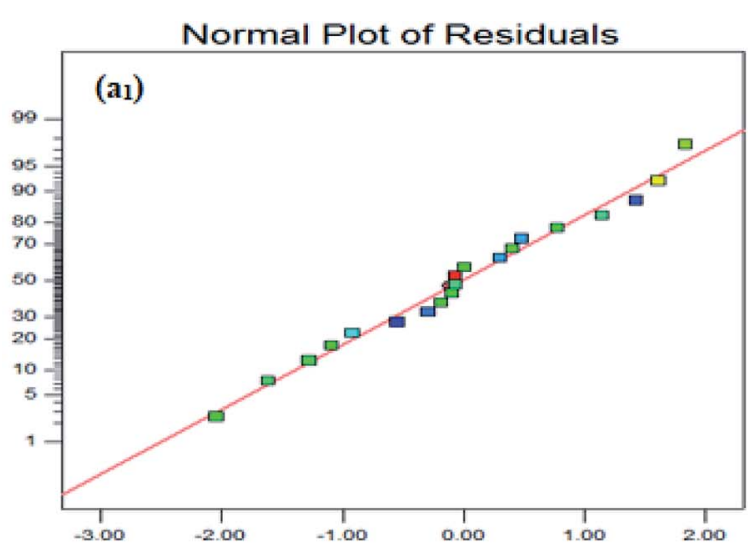

$\mathrm{X}$ : Internally Studentized Residuals, Y: Normal \% Probability

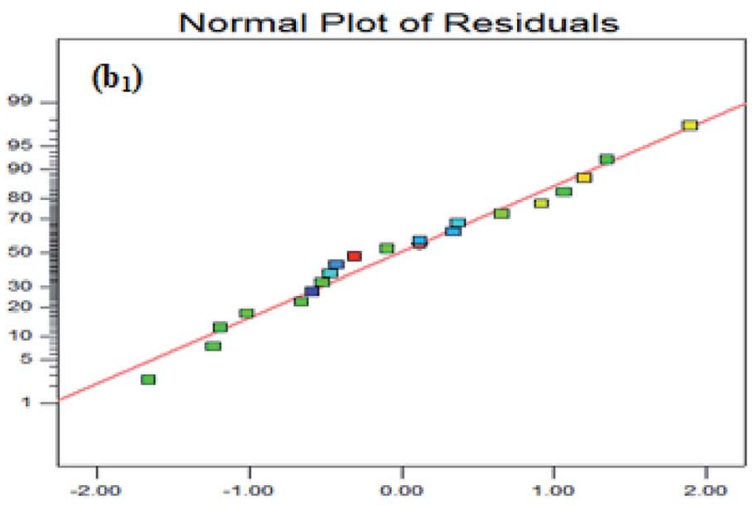

$\mathrm{X}$ : Internally Studentized Residuals, Y: Norma1 \%

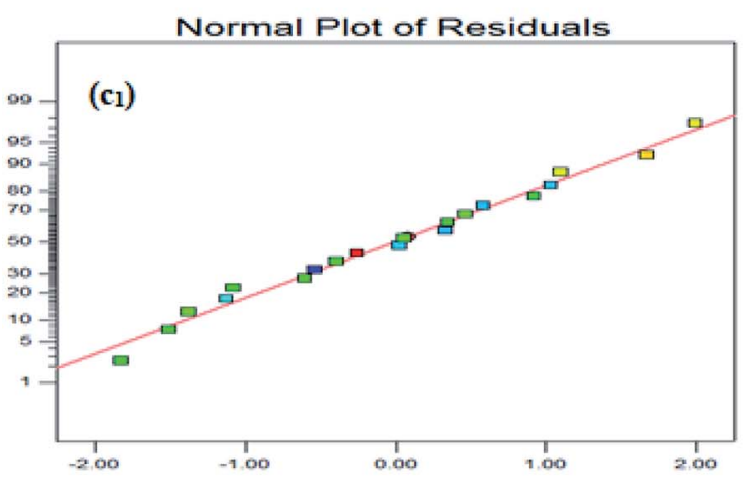

$\mathrm{X}$ : Internally Studentized Residuals, Y: Normal \%

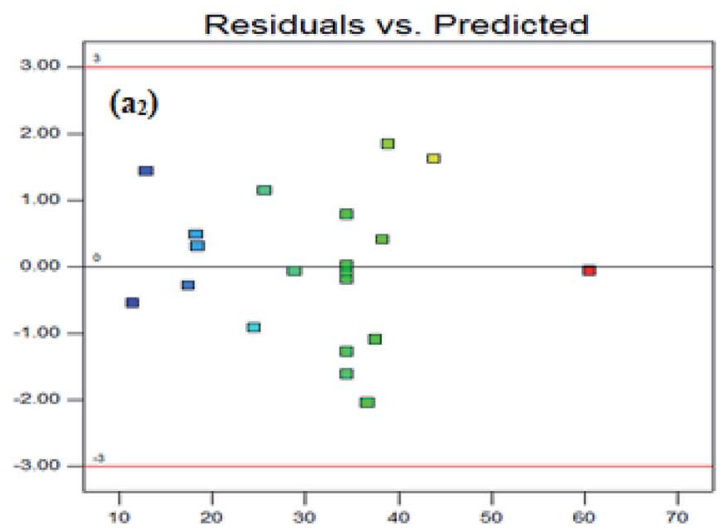

$\mathrm{X}$ : Predicted, Y: Internally Studentized Residuals

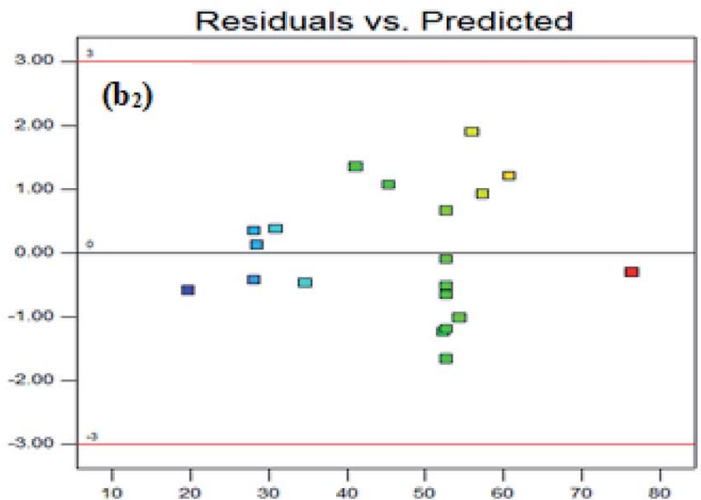

$\mathrm{X}$ : Predicted, Y: Internally Studentized Residuals

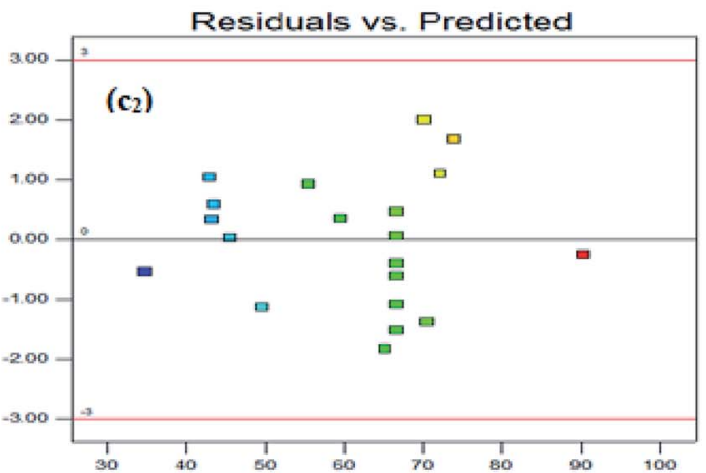

$\mathrm{X}$ : Predicted, Y: Internally Studentized Residuals

Fig. 1 Normal probability distribution of residuals for 2,4-D removal efficiency: $\left(a_{1}, b_{1}\right.$ and $\left.c_{1}\right)$, and Residuals versus predicted for 2,4-D removal efficiency $\left(\mathrm{a}_{2}, \mathrm{~b}_{2}\right.$ and $\mathrm{c}_{2}$ ); (a) $\mathrm{SS} 316 / \beta-\mathrm{PbO}_{2}$, (b) $\mathrm{Pb} / \beta-\mathrm{PbO}_{2}$ and (c) $\mathrm{G} / \beta-\mathrm{PbO}_{2}$. 
near to the straight line and no gross distribution is observed around the line. The adequacy of the models was also evaluated by the plot of residuals versus the predicted responses. As shown in Fig. $1\left(a_{2}, b_{2}\right.$ and $\left.c_{2}\right)$, the random scatter of the residuals around the zero specifies the appropriate behavior of the models and the satisfaction of constant variance assumptions. Furthermore, in a well-designed model, the residuals should be independent of time or any other parameters.

\subsection{Efficiency of electrodes in 2,4-D herbicide degradation}

In this study, the efficiency of coated anode electrodes (SS316/ $\beta$ $\mathrm{PbO}_{2}, \mathrm{~Pb} / \beta-\mathrm{PbO}_{2}, \mathrm{G} / \beta-\mathrm{PbO}_{2}$ ) was investigated in the degradation of 2,4-D herbicide. In oxidative degradation of organic compounds using $\mathrm{PbO}_{2}$ electrodes, the electro-generated physisorbed $\mathrm{HO}^{\circ}$ on the surface of electrode plays the main role in mineralization of the pollutants. The formation of adsorbed hydroxyl radical $\mathrm{MO}_{x}\left(\mathrm{HO}^{\circ}\right)$ by oxidation of the water molecules has been reported as the initial reaction in both kinds (active and non-active) of $\mathrm{MO}_{x}$ anodes, as shown in (eqn (1))..$^{32,43}$

$$
\mathrm{MO}_{x}+\mathrm{H}_{2} \mathrm{O} \rightarrow \mathrm{MO}_{x}\left(\mathrm{HO}^{*}\right)+\mathrm{H}^{+}+\mathrm{e}^{-}
$$

Afterward, the electrochemically generated $\mathrm{MO}_{x}\left(\mathrm{HO}^{\circ}\right)$, as one of the strongest oxidant, mineralize the organic matter (eqn (2)). ${ }^{32,43}$ Furthermore, the $\mathrm{MO}_{x}\left(\mathrm{HO}^{\circ}\right)$ can generate the $\mathrm{O}_{2}$ gas (eqn (3)); this reaction acts as a competitor for the reaction shown in eqn (2).

$$
\begin{aligned}
\mathrm{R}+\mathrm{MO}_{x}\left(\mathrm{HO}^{\cdot}\right) & \rightarrow m \mathrm{CO}_{2}+n \mathrm{H}_{2} \mathrm{O}+x \mathrm{H}^{+}+y \mathrm{e}^{-} \\
2 \mathrm{MO}_{x}\left(\mathrm{HO}^{\cdot}\right) & \rightarrow 2 \mathrm{MO}_{x}+\mathrm{O}_{2}+2 \mathrm{H}^{+}+2 \mathrm{e}^{-}
\end{aligned}
$$

According to reports, the oxygen evolution reaction is considerably dependent on the value of oxygen evolution overpotential; so that, the oxygen evolution reaction is identified as the dominant reaction for the electrodes with the low oxygen evolution over-potential. However, this reaction is difficult for the electrodes that have higher oxygen evolution over-potential and; thus, for these kinds of electrodes, the reaction (2) occurs earlier than the reaction (3), which it leads to progress the efficiency of the mineralization reaction. ${ }^{32,43}$

In order to determine the performance of the electrochemical process, the 2,4-D herbicide degradation was calculated as a response. A quadratic model describes the changes in 2,4-D degradation efficiency as a function of variables. According to Table 2, $\mathrm{A}(\mathrm{pH}), \mathrm{B}(\mathrm{j})$ and $\mathrm{C}$ (time) are the most important functions of the model for the electrochemical process using the $\mathrm{SS} / \beta-\mathrm{PbO}_{2}, \mathrm{~Pb} / \beta-\mathrm{PbO}_{2}$ and $\mathrm{G} / \beta-\mathrm{PbO}_{2}$ anode electrodes. The 2,4-D degradation efficiency using the coated electrodes was investigated at various $\mathrm{pH}$ values (3-11), electrolysis time (20-80 min) and current density (1-5 $\mathrm{mA} \mathrm{cm}{ }^{-2}$ ). The surface plot for 2,4-D degradation by the electrochemical process using SS316/ $\beta-\mathrm{PbO}_{2}, \mathrm{~Pb} / \beta-\mathrm{PbO}_{2}$ and $\mathrm{G} / \beta-\mathrm{PbO}_{2}$ anode electrodes is depicted in (Fig. 2 (Part I-III)) and is representative of the interaction effect of time and $\mathrm{pH}$. As can be seen, increasing the electrolysis time and reducing the $\mathrm{pH}$ enhanced the 2,4-D degradation efficiency. As the results showed, by decreasing the $\mathrm{pH}$ from 11 to 3 under the same conditions $\left(j=5 \mathrm{~mA} \mathrm{~cm}^{-2}\right.$, time $\left.=80 \mathrm{~min}\right)$, the efficiency of the electrochemical process in degradation of $2,4-\mathrm{D}$ using the $\mathrm{SS} 316 / \beta-\mathrm{PbO}_{2}, \mathrm{~Pb} / \beta-\mathrm{PbO}_{2}$ and $\mathrm{G} / \beta-\mathrm{PbO}_{2}$ electrodes was increased by $26.5,25.7$ and $27.7 \%$, respectively. In addition, the degradation efficiency of this herbicide using $\mathrm{SS} 316 / \beta-\mathrm{PbO}_{2}, \mathrm{~Pb} / \beta-\mathrm{PbO}_{2}$ and $\mathrm{G} / \beta-\mathrm{PbO}_{2}$ was increased by 37.2 , 42.0 and $42.2 \%$ by an increase in the electrolysis time from 20 to 80 under identical conditions $\left(j: 5 \mathrm{~mA} \mathrm{~cm}^{-2}, \mathrm{pH}=3\right.$ ) (Fig. 2 (Part I-III)), respectively. Also, the results showed that 2,4-D degradation efficiency using the $\mathrm{SS} 316 / \beta-\mathrm{PbO}_{2}, \mathrm{~Pb} / \beta-\mathrm{PbO}_{2}$ and $\mathrm{G} / \beta-\mathrm{PbO}_{2}$ electrodes varied between $10.6-60.4 \%, 18.7-75.9 \%$ and $33.9-89.8 \%$, respectively. The highest $2,4-\mathrm{D}$ degradation efficiency was observed at $\mathrm{pH}=3$, time $=80 \min$ and $j=5 \mathrm{~mA}$ $\mathrm{cm}^{-2}$. It was found that the lowest efficiency is achieved at the maximum $\mathrm{pH}$ value and the lowest electrolysis time and current density. It was evident that the $\mathrm{pH}$ was more effective on the 2,4D degradation efficiency compared to electrolysis time. The obtained results are consistent with the results of Aquino Neto et al. (2009); ${ }^{44}$ in their study, it was observed that increasing the $\mathrm{pH}$ from 2 to 11 is led to decrease the degradation efficiency of glyphosate herbicide (GH); so that, the highest GH degradation was achieved at $\mathrm{pH}=2(38 \%)$. In their study, the lower $\mathrm{pH}$ values diminished the oxygen evolution reaction in favor of organic compound oxidation, ${ }^{44}$ which is agreed with the results of the present study. Jaafarzadeh et al. (2018) observed that decreasing the $\mathrm{pH}$ and increasing the electrolysis time are led to improve the 2,4-D removal efficiency; it is in line with the present study. ${ }^{41}$ In the present study, increasing the 2.4-D degradation in acidic $\mathrm{pH}$ can be attributed to the higher efficiency of the hydroxyl radical production in acidic $\mathrm{pH}$ values and production of some ions such as $\mathrm{Cl}, \mathrm{Cl}_{2}$ and $\mathrm{HOCl}$ that have higher efficiency at acidic $\mathrm{pH}$ values. ${ }^{45,46}$ The effect of current density on the degradation of 2,4-D is presented in Fig. 2 (Part IIII (a-c)). Considering the figuers from (Fig. 2 Part I (a-c)) to (Fig. 2 Part III $(\mathrm{a}-\mathrm{c})$ ), it can be concluded that increasing the current density leads to reducing the electrolysis time and increasing the efficiency of 2,4-D herbicide degradation. The greater hydroxyl radical generation at the higher current density may be the reason for this event; so that, the herbicide degradation efficiency using $\mathrm{SS} 316 / \beta-\mathrm{PbO}_{2}$ electrodes (from 36.0 to $60.4 \%$ ), $\mathrm{Pb} / \beta-\mathrm{PbO}_{2}$ (from 52.6 to $75.6 \%$ ) and $\mathrm{G} / \beta-\mathrm{PbO}_{2}$ (68.1 to $89.8 \%$ ) is developed by increasing the current density from 1 $\mathrm{mA} \mathrm{cm}{ }^{-2}$ to $5 \mathrm{~mA} \mathrm{~cm}^{-2}$ at the same conditions $(\mathrm{pH}=3$ and time $=80 \mathrm{~min}$ ), which is consistent with the study conducted by Jaafarzadeh et al. (2018). ${ }^{41}$ In their study, the results showed that increasing the current density increases the removal efficiency of herbicide; so that, increasing the current from $10 \mathrm{~mA}$ $\mathrm{cm}^{-2}$ to $40 \mathrm{~mA} \mathrm{~cm}{ }^{-2}$ is led to enhance the removal efficiency from $52 \%$ to $82 \% .{ }^{41}$ In the study conducted by Yahiaoui et al. (2013), it was observed that the tetracycline (TC) removal efficiency is developed by increasing the current density; so that, the removal efficiency increased from 33.5 to $77.7 \%$ by increasing the current density from 2.5 to $25 \mathrm{~mA} \mathrm{~cm}{ }^{-2},{ }^{47}$ which is in accordance with the present study. As discussed before, this effect should be related to increasing the production of electrogenerated $\mathrm{OH}^{*}$ radicals from the water discharge by increasing current density. 
(A)
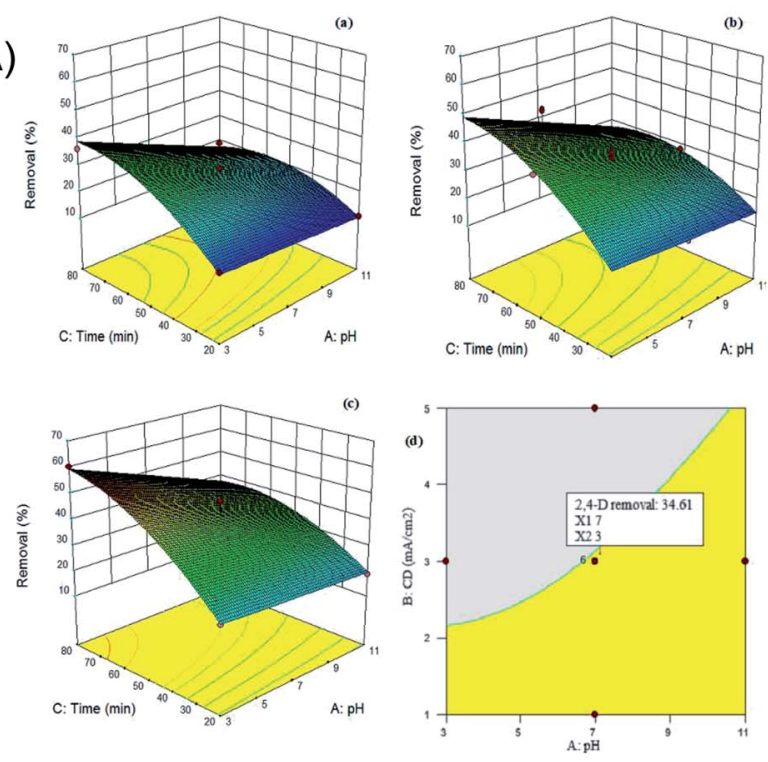

(C)
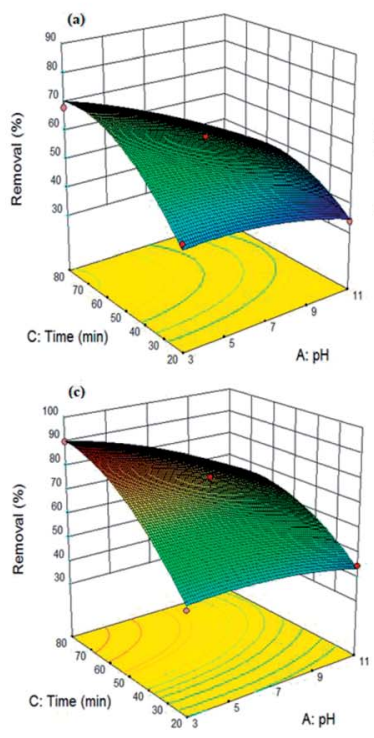

(B)
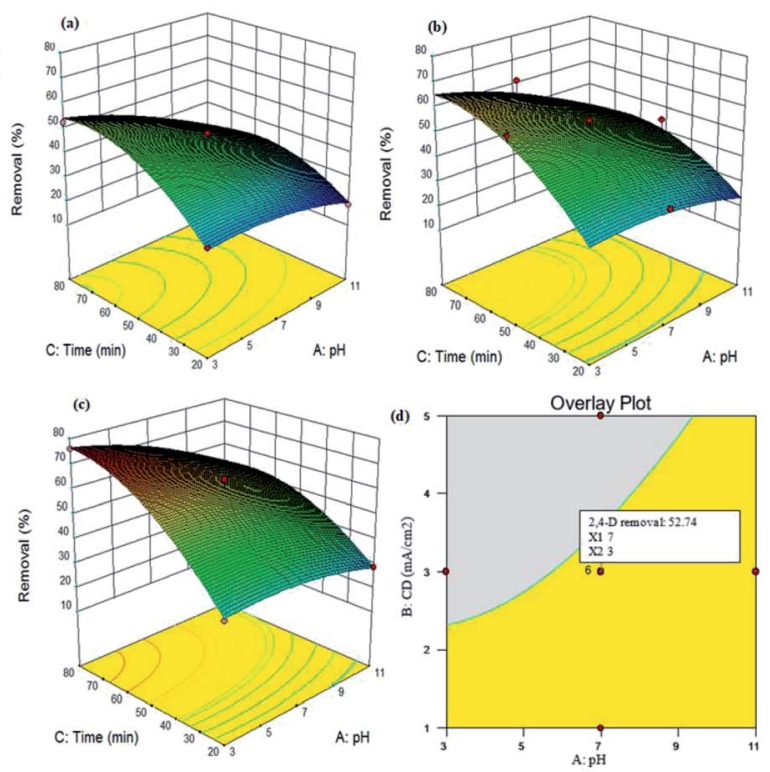
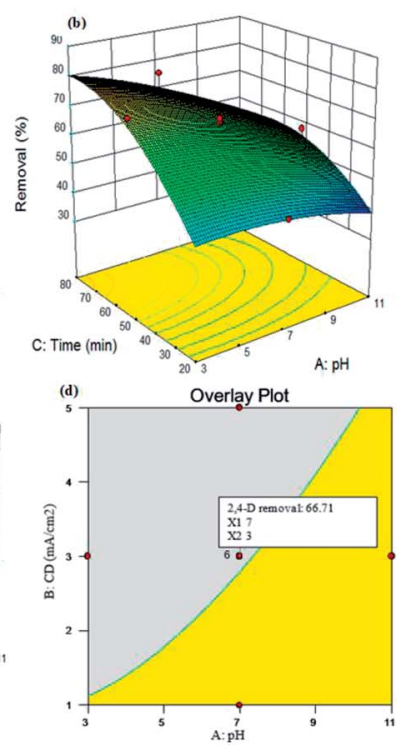

Fig. 2 Response surface plot for electrochemical process with different anode electrodes; $\mathrm{SS} 316 / \beta-\mathrm{PbO} \mathrm{O}_{2}$ anode $(\mathrm{Part} \mathrm{I}), \mathrm{Pb} / \beta-\mathrm{PbO} 2$ anode $(\mathrm{Part}$ II) and G/ $\beta-\mathrm{PbO}_{2}$ anode (Part III): (a) $j: 1 \mathrm{~mA} \mathrm{~cm}^{-2}$, (b) $j: 3 \mathrm{~mA} \mathrm{~cm}{ }^{-2}$, (c) $j: 5 \mathrm{~mA} \mathrm{~cm}^{-2}$ and (d) overlay plot for optimal region (pH:7, j: $3 \mathrm{~mA} \mathrm{~cm}{ }^{-2}$, time: $50 \mathrm{~min}$ ).

The results showed that all three types of electrodes have suitable performance in degradation of the 2,4-D herbicide; but among them, the $\mathrm{G} / \mathrm{\beta}-\mathrm{PbO}_{2}$ anode electrode was able to provide the highest herbicide degradation efficiency compared to other studied electrodes. The high potential of the $\mathrm{G} / \beta-\mathrm{PbO}_{2}$ can be considered as the reason for its superior performance in the electrochemical generation of $\mathrm{HO}^{*}$ radicals compared to other studied electrodes. The properties of $\mathrm{G} / \beta-\mathrm{PbO}_{2}$ electrode include the high oxygen evolution potential, good electric conductivity, good electrodeposition and high specific area, which lead to the exceptional performance of this electrode. ${ }^{32,48-50}$

To justify the performance of $\beta-\mathrm{PbO}_{2}$ electrodes in the process of electro-catalytic degradation of the 2,4-D herbicide, the experiment was carried out to determine the anodic potential of the three electrodes prepared $\left(\mathrm{SS} / \beta-\mathrm{PbO}_{2}, \mathrm{~Pb} / \beta-\mathrm{PbO}_{2}\right.$ and $\mathrm{G} / \beta$ $\mathrm{PbO}_{2}$ ) for water oxidation in $0.25 \mathrm{M} \mathrm{Na}_{2} \mathrm{SO}_{4}$ electrolyte solution at $\mathrm{pH}$ of 6 and scan speed of $100 \mathrm{mV} \mathrm{s}^{-1}$. Fig. 3 shows that the oxygen evolution over-potential is high for all three electrodes, and these electrodes have well expanded the potential window of the water oxidation. According to Fischbacher et al. (2013), the high oxygen evolution over-potential on the surface of these electrodes produces a large amount of $\mathrm{HO}^{\circ}$, which increases the oxidation efficiency and improves the performance of these electrodes for degradation of organic pollutants. ${ }^{51}$

According to this data, our $\beta-\mathrm{PbO}_{2}$ electrodes clearly have high oxygen overpotential and produces effectively $\mathrm{H}_{2} \mathrm{O}_{2}$ and $\mathrm{O}_{3}$. According to the reaction shown below, the reaction of generated $\mathrm{H}_{2} \mathrm{O}_{2}$ with $\mathrm{O}_{3}$ produces hydroxyl radicals. 


$$
\mathrm{H}_{2} \mathrm{O}_{2}+2 \mathrm{O}_{3} \rightarrow 2 \mathrm{HO}^{\circ}+3 \mathrm{O}_{2}
$$

\subsection{Process optimization and validation of the model}

The experiments were performed based on CCD to attain the process optimization. In this study, 3 independent variables, i.e., $\mathrm{pH}$, current density and electrolysis time were evaluated to processing the optimization of the electrochemical process for three anodes electrodes $\left(\mathrm{SS} 316 / \beta-\mathrm{PbO}_{2}, \mathrm{~Pb} / \beta-\mathrm{PbO}_{2}\right.$ and $\mathrm{G} / \beta$ $\mathrm{PbO}_{2}$ ). Graphical optimization produces an overlay plot, which affirms the possibility of response value in the factor space. Overlay plot is indicative of the region, which meets the proposed criteria. The optimum area related to 3 responses was determined (Fig. 2 (Part I-III, d)). The yellow region shows the region that gratifies the responses and the shaded region are related to variables of space. The yellow zone covers the $\mathrm{pH}$ of 7 and $j$ of $3 \mathrm{~mA} \mathrm{~cm}^{-2}$ for the electrolysis time of $50 \mathrm{~min}$. To verify the accuracy of the models, one point in optimal areas is selected (conditions shown by the flag are shown in Fig. 2 (Part I-III, d)). The electrochemical process was used to compare the actual values with the predicted values of responses. Table 3 shows the results of the experiment in optimal areas. The correctness of the optimum conditions was examined by DOE software using standard deviation for each response. The actual values are very close to the predicted values of the model. According to the response, the optimum region for 2,4-D herbicide degradation using three anodes electrodes, i.e., $\mathrm{SS} 316 / \beta-\mathrm{PbO}_{2}, \mathrm{~Pb} / \beta-\mathrm{PbO}_{2}$ and $\mathrm{G} / \beta-\mathrm{PbO}_{2}$ were identified to be $33.9 \%, 50.8 \%$ and $65.3 \%$, respectively.

In optimum conditions, the energy consumption (EC) for three $\mathrm{SS} 316 / \beta-\mathrm{PbO}_{2}, \mathrm{~Pb} / \beta-\mathrm{PbO}_{2}$ and $\mathrm{G} / \beta-\mathrm{PbO}_{2}$ electrodes was investigated (Fig. $\mathrm{S} 4 \dagger$ ). The results showed that the EC for the three electrodes of $\mathrm{SS} 316 / \beta-\mathrm{PbO}_{2}, \mathrm{~Pb} / \beta-\mathrm{PbO}_{2}$ and $\mathrm{G} / \beta-\mathrm{PbO}_{2}$ was $6.46,6.15$ and $5.67 \mathrm{~kW} \mathrm{~h} \mathrm{~m}{ }^{-3}$, respectively. According to the results, the $\mathrm{G} / \beta-\mathrm{PbO}_{2}$ electrode has a lower EC compared to two other electrodes due to high efficiency in the 2,4-D herbicide degradation, which it was even lower than the EC reported in studies conducted by Pipi et al. (2014), ${ }^{52}$ Souza et al. (2015), ${ }^{53}$ Hashim et al. (2017 (ref. 54)) and Kobya et al. (2016); ${ }^{55}$ in the mentioned studies, the energy consumption was observed to be 16.9, 455.5, 6.21 and $11.17 \mathrm{~kW} \mathrm{~h} \mathrm{~m}^{-3}$, respectively.

\subsection{Mechanism of 2,4-D herbicide degradation}

The determination of oxidation mechanisms of 2,4-D herbicide was carried out by electrolysis of $100 \mathrm{ppm}$ of the solution in $0.1 \mathrm{M} \mathrm{Na}_{2} \mathrm{SO}_{4}$ at $\mathrm{pH}=3 \mathrm{using}$ the current density of $3 \mathrm{~mA} \mathrm{~cm}^{-2}$ for $80 \mathrm{~min}$. During the electrolysis process, the results were followed up by a cyclic voltammetric technique on the surface of the glassy carbon electrode.

As shown in Fig. 4 (Part I), during the electrolysis process, the peak current of $A_{1}$ was reduced and new peaks of $C_{0}$ and $A_{0}$ emerged. Reducing the peak current of $\mathrm{A}_{1}$ indicates the consumption of the raw material of the herbicide and the appearance and increase of the peaks of the $\mathrm{C}_{0}$ and $\mathrm{A}_{0}$ represents the formation of the intermediates, which are produced during the electrolysis process. As seen in Fig. 4 (Part II), at the beginning of the electrolysis, the peak current of $A_{1}$ diminished and the peaks of $A_{0} / C_{0}$ begin to emerge. This process continues until the peak of $\mathrm{A}_{1}$ disappears completely. The complete removal of $A_{1}$ peak shows the complete degradation of the 2,4-D herbicide. According to the Scheme 1 and Fig. 4 (Part III), it is observed that the 5-benzoquinone and 5-parabensucinone are the byproducts and intermediates resulted from the oxidation of the 2,4-D herbicides. Also, the appearance of the $A_{0} / C_{0}$ peak during electrolysis specifies the presence of these intermediate in this electrolysis (Fig. 4 (Part III)).

By the continuation of the electrolysis process, the peaks of $\mathrm{A}_{0} / \mathrm{C}_{0}$ started to decrease and, finally, these peaks also disappeared completely, which it is indicative of the complete degradation of the intermediate formed during the electrolysis process (Scheme 2). The empirical observations in the Souza et al. $(2015)^{53}$ and the empirical data validates the mechanism presented in Scheme 2.

The comparison of the 2,4-D degradation mechanism using the $\mathrm{PbO}_{2}$ coated electrode and the un-coated electrodes used in previous studies disclosed that, using the $\beta-\mathrm{PbO}_{2}$, the 2,4-D herbicide as well as the intermediates generated during the electrolysis process are completely degraded and the final products of degradation are the water $\left(\mathrm{H}_{2} \mathrm{O}\right)$ and carbon dioxide $\left(\mathrm{CO}_{2}\right)$ (Fig. 4 (Part I and II) and Scheme 2); however, the uncoated graphite and SS316 can only degrade the herbicide and are not able to degrade the intermediates during the electrolysis and, as a result, these intermediates remain as the byproducts in final solution after electrolysis (Fig. 4 (Part III) and Scheme 1). $\mathrm{PbO}_{2}$, due to having the high overvoltage for production of the oxygen and high potential window for oxidation of water, is capable to electrochemically production of the strong oxidizing species such as ozone $\left(\mathrm{O}_{3}\right)$ and hydrogen peroxide $\left(\mathrm{H}_{2} \mathrm{O}_{2}\right)$ during the electrolysis process, which the reactions between these two oxidants are led to produce the hydroxyl radical. The electrochemically produced hydroxyl radical through the reaction between the $\mathrm{O}_{3}$ and $\mathrm{H}_{2} \mathrm{O}_{2}$ and through the decomposition of the water on the surface of the $\mathrm{Pb}$ electrode are the driving force and the main factor leading to fulfill the degradation process and to convert the raw material and the intermediate formed during the electrolysis process to water $\left(\mathrm{H}_{2} \mathrm{O}\right)$ and carbon dioxide $\left(\mathrm{CO}_{2}\right)^{\mathbf{8 , 1 6 , 3 2 , 5 3 , 5 6}}$ It should be noted that the proposed mechanism for degradation the 2,4-D herbicide in this study was reported based on the results of LC/ MS, GC/MS and HPLC in the studies conducted by Souza et al. (2015), ${ }^{53}$ Sanchis et al. (2013), ${ }^{8}$ Jaafarzadeh et al. (2018), ${ }^{41}$ Fontmorin et al. $(2012)^{16}$ and according to results of LC/MS spectrum obtained in our previous study ${ }^{34}$ and the electrochemical data obtained in our current study. Furthermore, in order to prove the proposed mechanism for degradation of 2,4D herbicide and identification of intermediates, after $80 \mathrm{~min}$, electrolysis was stopped and the LC-MS spectrum of the 2,4-D herbicide solution was provided. Table 4 and Fig. S5 $\uparrow$ shows the presence of molar mass for each of the intermediates in the corresponding spectrum, which it is accounted for as the reason for the correctness of pathway for the degradation of the 2,4-D herbicide and the proposed mechanism (Schemes 1 and 2). 


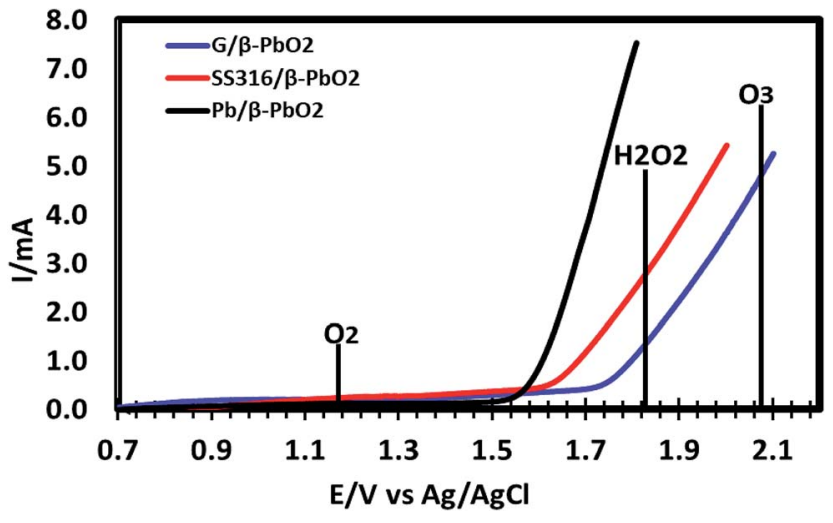

Fig. 3 LSV grame of $\beta-\mathrm{PbO}_{2}$ electrodes in $\mathrm{Na}_{2} \mathrm{SO}_{4}(0.25 \mathrm{M})$ at $\mathrm{pH}=$ 6.0. Scan rate $=100 \mathrm{mV} \mathrm{s}^{-1}$.

\subsection{Comparison of electrodes potential in degradation of} 2,4-D and removal of COD and TOC

In EAOPs, the degradation of the target pollutant is not adequate; hence, the mineralization of organic pollutants should be evaluated, which was determined by the determination of COD and TOC. In this study, the COD and TOC removal efficiency using all three types of coated electrodes (SS316/ $\beta$ $\mathrm{PbO}_{2}, \mathrm{~Pb} / \beta-\mathrm{PbO}_{2}$ and $\mathrm{G} / \beta-\mathrm{PbO}_{2}$ ) were investigated when the electrochemical process had the highest 2,4-D degradation efficiency (Fig. S6 $\dagger$ ). The results showed that the COD removal efficiency using $\mathrm{SS} 316 / \beta-\mathrm{PbO}_{2}, \mathrm{~Pb} / \beta-\mathrm{PbO}_{2}$ and $\mathrm{G} / \beta-\mathrm{PbO}_{2}$ electrodes were $51.7,68.7$ and $83.7 \%$, respectively, while the TOC removal efficiency using the electrodes studied in the same conditions was $41.3,56.6$ and $78.5 \%$. Also, 2,4-D degradation efficiency by the electrodes studied (SS316/ $\beta-\mathrm{PbO}_{2}, \mathrm{~Pb} / \beta-\mathrm{PbO}_{2}$ and $\mathrm{G} / \beta-\mathrm{PbO}_{2}$ ) in the same conditions was $60.4,75.9$ and $89.8 \%$, respectively. This disclosed the considerable degradation of the 2,4-D by the electrochemical system using the electrodes studied, which is consistent with the Zourab et al. (2009). ${ }^{57}$ Zourab et al. revealed that the electro-catalytic degradation efficiency of herbicidal and pure of 2,4-D using the $\mathrm{Pb} / \mathrm{PbO}_{2}$ electrode was $79 \%$ and $57 \%$, while the COD removal was $75 \%$ and $56 \%$, respectively. They also observed that the reduction in the 2,4-D herbicide was proportional to decreasing the COD content of the solution, which it indicates the 2,4-D degradation by the electrochemical process using the $\mathrm{Pb} / \mathrm{PbO}_{2}$ anode electrode. ${ }^{57}$ In another study, Abu Ghalwa et al. observed that the highest COD removal for herbicide linuron using two types of $\mathrm{Pb} / \mathrm{PbO}_{2}$ and $\mathrm{C} / \mathrm{PbO}_{2}$ electrodes was obtained to be $92 \%$ and
$84 \%$, respectively, which reveals a relatively complete degradation of linuron herbicide by the $\mathrm{Pb} / \mathrm{PbO}_{2}$ electrode. ${ }^{58}$ Furthermore, the results of this study showed that $\mathrm{G} / \beta-\mathrm{PbO}_{2}$ are the better electrodes among these three electrodes studied due to providing the highest 2,4-D degradation efficiency. The greater 2,4-D degradation efficiency and higher COD removal efficiency using the $\mathrm{G} / \beta-\mathrm{PbO}_{2}$ electrode can be explained by two following reasons: (1) the presence of a greater amount of $\mathrm{PbO}_{2}$ on graphite electrode compared to other electrodes, which it offers the greater number of sites to produce the hydroxyl radicals, and (2) the lowest crystals size values for $\beta-\mathrm{PbO}_{2}$ compared to other electrodes ( $\left.\mathrm{SS} 316 / \beta-\mathrm{PbO}_{2}, \mathrm{~Pb} / \beta-\mathrm{PbO}_{2}\right)$ (Fig. S3 (Part I) $\dagger$ ). Based on the reports, the smaller crystals size provides a greater surface area and, as a result, it increases the electro-generation of $\mathrm{HO}^{\circ}$ that is favorable for the degradation of the pollutants. ${ }^{32,33,59}$

\subsection{Electrochemical stability test}

High electrochemical stability is considered an important feature of the electrodes, especially for their industrial applications. The life-time of the $\beta-\mathrm{PbO}_{2}$ electrodes is drastically dependent on the coating condition, surface morphology, compactness and uniformity of the formed coating. The lifetime of the electrodes was observed to be similar to the previous study. ${ }^{32,60,61}$ In order to evaluate and to compare the stability of the studied electrodes, the accelerated service life experiments were carried out using the chronopotentiometry at the constant anodic current density of $100 \mathrm{~mA} \mathrm{~cm}^{-2}$.

According to deactivation of the electrode by increasing the cell potential to $10 \mathrm{~V}$, the life-time of electrodes studied are observed to be as follows: $\mathrm{G} / \mathrm{PbO}_{2}(80 \mathrm{~h})>\mathrm{SS} / \mathrm{PbO}_{2}$ electrode (52 h) $>\mathrm{Pb} / \mathrm{PbO}_{2}$ electrode $(40 \mathrm{~h}) .{ }^{46}$ The remarkable stability of the graphite electrode may be due to several factors. One of these factors is the penetration of lead dioxide particles into the inner layers of the graphite bed, which provides more interaction and adhesion of the $\mathrm{PbO}_{2}$ film to the graphite substrate. Another factor, as shown in SEM (Fig. S3, Part I $\dagger$ ) and XRD (Fig. S3, Part III $\dagger$ ) images, is the fact that decreasing the size of $\beta-\mathrm{PbO}_{2}$ particles on the graphite surface can reduce the defect density at the electrode surface and increase the electrochemical stability of $\mathrm{G} / \beta-\mathrm{PbO}_{2} \cdot{ }^{32}$ Therefore, the modification of the surface of the electrodes not only decreases or eliminates the possibility of the penetration of electrolyte through the cracks and pores but also leads to an increase in internal pressure caused by the production of oxygen gas inside the electrode. Furthermore, the greater life-time of the $\mathrm{SS} 316 / \beta-\mathrm{PbO}_{2}$ electrode, compared to the

Table 3 Verification of experimental results at optimum conditions, $\left(\mathrm{pH}: 7, j: 3 \mathrm{~mA} \mathrm{~cm}{ }^{-2}\right.$ and electrolysis time $\left.50 \mathrm{~min}\right)$

2,4-D herbicide degradation (\%)

\begin{tabular}{llll} 
Optimum condition & $\mathrm{SS} 316 / \beta-\mathrm{PbO}_{2}$ & $\mathrm{~Pb} / \beta-\mathrm{PbO}_{2}$ & $\mathrm{G} / \beta-\mathrm{PbO}{ }_{2}$ \\
\hline Experimental results & $33.94 \%$ & $50.89 \%$ & $65.34 \%$ \\
Model response & $\mathrm{CI}$ low: 32.24, CI high: 36.42 & CI low: 49.54, CI high: 54.67 & $\mathrm{CI}$ low: $63.72, \mathrm{CI}$ high: 68.56 \\
Error & 0.97 & 1.18 & 1.12 \\
Standard deviation & \pm 3.06 & \pm 3.75 & \pm 3.54
\end{tabular}


(A)

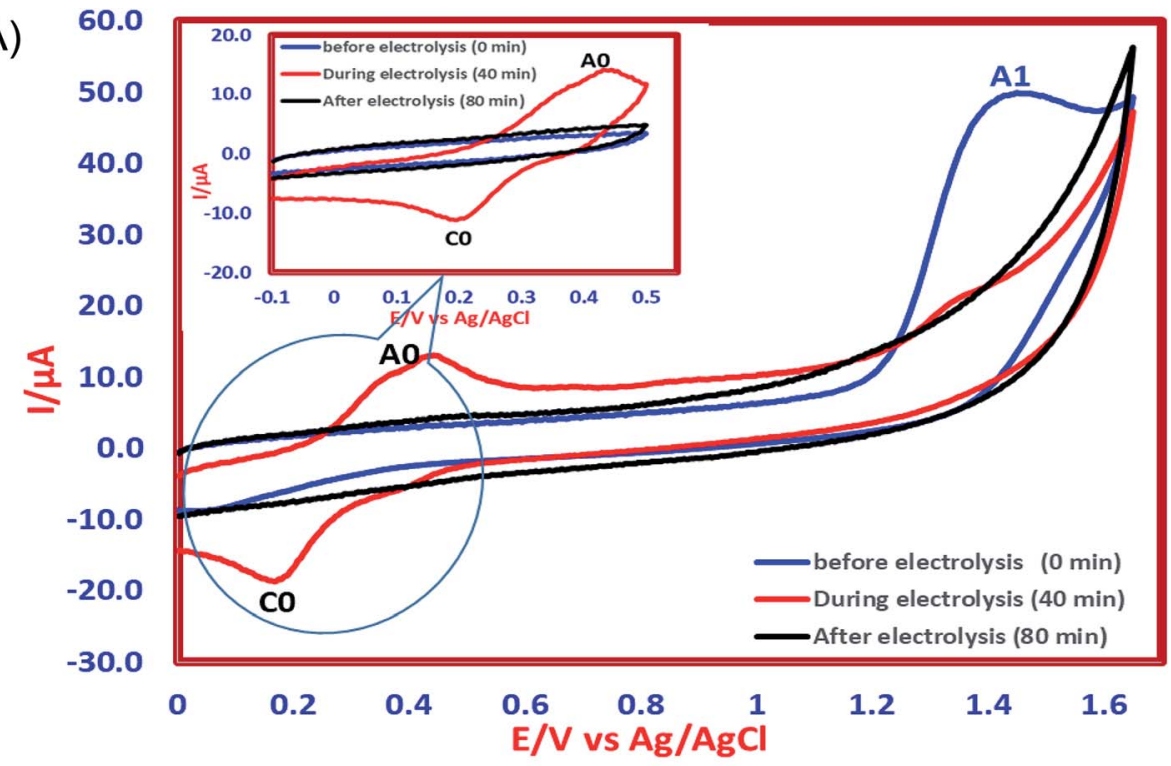

(B)

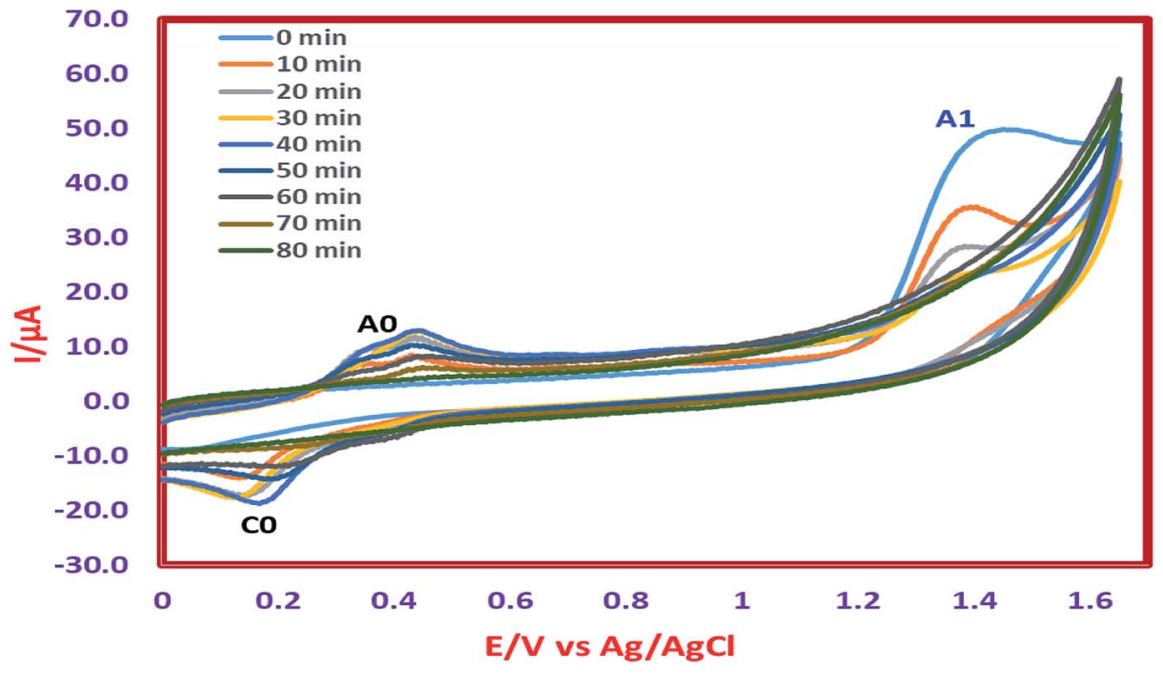

(C)

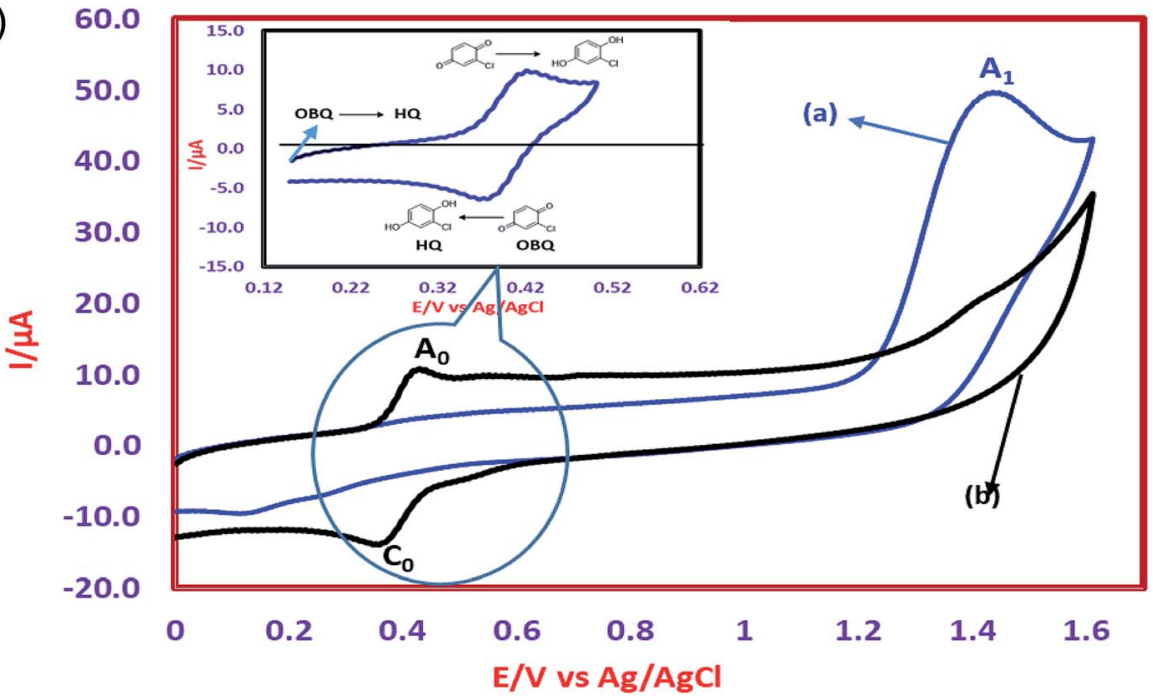

Fig. 4 (Part I) Degradation of 2,4-D solution before, during and after electrolysis using modified $\beta$-PbO2 electrodes, (Part II) degradation of 2,4-D solution during different electrolysis times using modified $\beta-\mathrm{PbO}_{2}$ electrodes (Part III) (a) degradation of 2,4-D solution before and (b) after electrolysis using unmodified electrodes (at $\mathrm{pH}=3$ in constant current electrolysis processes monitored by cyclic voltammetry technique at $100 \mathrm{mV} \mathrm{s}^{-1}$ in $0.1 \mathrm{M} \mathrm{Na}_{2} \mathrm{SO}_{4}$ on a glassy carbon electrode). 


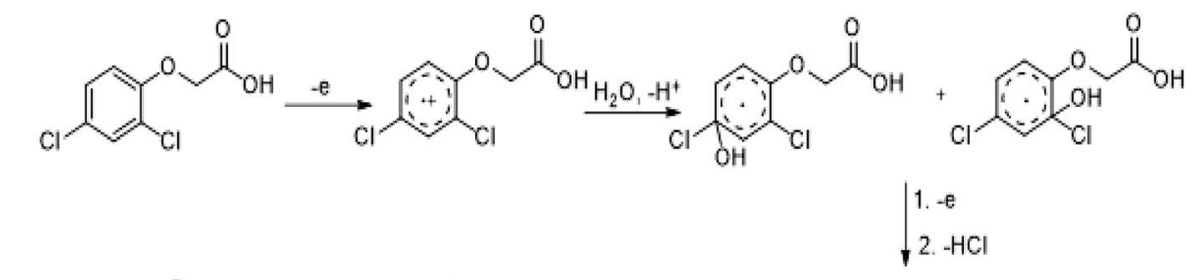

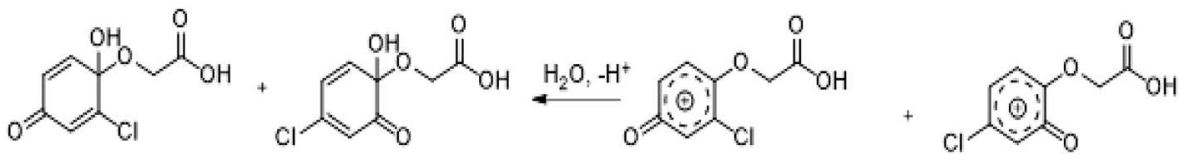
$-\mathrm{HOCH}_{2} \mathrm{COOH}$<smiles>O=C1C=C(Cl)C(=O)C(=O)C1</smiles>

Scheme 1 Proposed pathway for electrocatalytic degradation of 2,4-D herbicide by anodic oxidation on unmodified graphite, $\mathrm{Pb}$ and stainless still electrodes.

$\mathrm{Pb} / \beta-\mathrm{PbO}_{2}$ electrode, can be due to the smooth and dense morphology of coated lead dioxide particles, which inhibits the penetration of the electrolyte into the coating and the formation of a passive layer on the surface. In addition, due to the improvement of the oxygen evolution potential (OEP) for $\mathrm{G} / \beta$ $\mathrm{PbO}_{2}$ and $\mathrm{SS} 316 / \beta-\mathrm{PbO}_{2}$ electrodes, the penetration of reactive oxygen species into the stainless steel and graphite bed is also inhibited.

\subsection{Leaching of lead ions}

Leaching of lead ions $\left(\mathrm{Pb}^{2+}\right)$ was evaluated after the electrolysis and the complete degradation of the 2,4-D and the results were represented in Fig. S7. $\dagger$ The evaluation of the leaching of $\mathrm{Pb}^{2+}$ was carried out by an electrochemical method through the cyclic voltammetry. Accordingly, $0.5 \mathrm{mg} \mathrm{L}^{-1} \mathrm{~Pb}\left(\mathrm{NO}_{3}\right)_{2}$ was

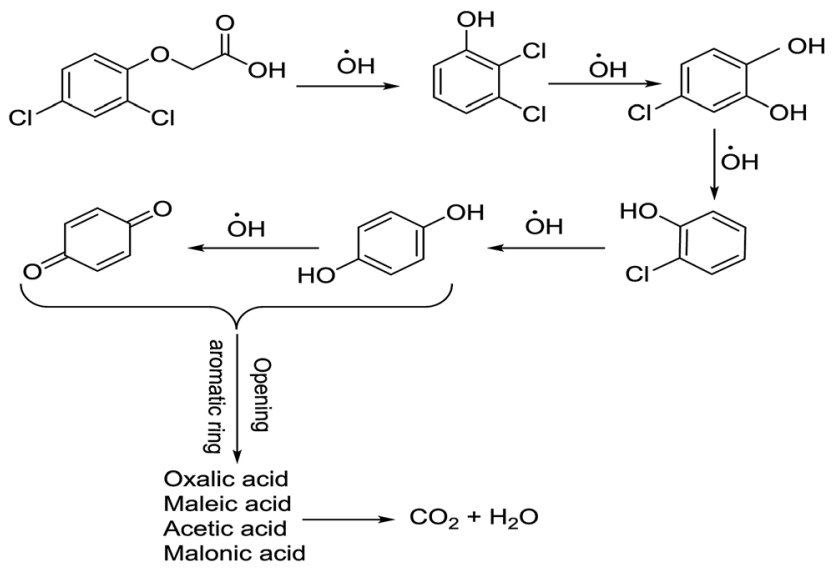

Scheme 2 Proposed pathway for electrocatalytic degradation of 2,4$\mathrm{D}$ herbicide by anodic oxidation on modified $\mathrm{G} / \beta-\mathrm{PbO}_{2}, \mathrm{SS} 316 / \beta$ $\mathrm{PbO}_{2}$ and $\mathrm{Pb} / \beta-\mathrm{PbO}_{2}$ electrodes. added to the final solution after electrolysis and the corresponding voltammogram was compared with the voltammogram of the final solution. As shown in Fig. S6, $\uparrow$ the peak related to oxidation of the $\mathrm{Pb}^{2+}$ is observed at the potential of $-0.5 \mathrm{~V} v s$. $\mathrm{Ag} / \mathrm{AgCl}$, which such a peak is not detected in the voltammogram of the final solution. According to this test, it can be well demonstrated that, during electrolysis and after the complete degradation of the herbicide, there is no leaching of $\mathrm{Pb}^{2+}$ ions into the solution from the electrode surface. This illustrates that the $\mathrm{PbO}_{2}$ coated on the surface of the electrodes is significantly stable which it was in agreement with the results of Ansari et al. (2018). Ansari et al. (2018) utilized the $\beta-\mathrm{PbO}_{2}$ electrodes for electro-catalytic degradation of the malachite green. In their study, the leaching of $\mathrm{Pb}^{2+}$ into the solution, in addition to cyclic voltammogram technique, was also measured using the ICP-OES device. The results showed that the concentration of $\mathrm{Pb}^{2+}$ ions in the electrolyzed solution was $0.0035 \mathrm{mg} \mathrm{L}^{-1} \cdot{ }^{32}$ Also, leaching levels of lead ions were evaluated using ICP-OES after the completion of the 2,4-D degradation process using $\mathrm{G} / \beta-\mathrm{PbO}_{2}$ electrode. According to results, after completion of the process, the $\mathrm{Pb}^{2+}$ concentration was observed to be $0.0013 \mathrm{ppm}$; the observed value was less than WHO guideline $\left(0.01 \mathrm{mg} \mathrm{L}^{-1}\right)$ for drinking water. ${ }^{50}$ Moreover, the $\mathrm{Pb}^{4+}$ concentration was not observed.

\section{Conclusions}

The electrocatalytic degradation of 2,4-dichlorophenoxyacetic acid (2,4-D) herbicide was studied by various coated electrodes $\left(\mathrm{SS} 316 / \beta-\mathrm{PbO}_{2}, \quad \mathrm{~Pb} / \beta-\mathrm{PbO}_{2}\right.$ and $\mathrm{G} / \beta-\mathrm{PbO}_{2}$ ). The Central Composite Design (CCD) using the response surface study (RSM) was found to be successful to determine the optimum conditions. The effect of three variables, e.g., $\mathrm{pH}$, electrolysis time and current density $(j)$ on the performance of the system 
Table 4 Identified products by LC-MS in the electrocatalytic degradation of 2,4-D herbicide by anodic oxidation $\left([2,4-D]_{0}=100 \mathrm{mg} \mathrm{L}^{-1}, j\right.$ $=3.0 \mathrm{~mA} \mathrm{~cm}{ }^{-2}$, electrolysis time $=80 \mathrm{~min}$ and $\mathrm{pH}=3$ )

Molecular weight

is observed $\left(\mathrm{g} \mathrm{mol}^{-1}\right)$

Intermediate molecular structure

$161-163$

159

$143-144$

111-112

104-105

$88-90$

$62-64$<smiles>Oc1ccc(Cl)cc1Cl</smiles><smiles>Oc1cc(O)c(Cl)cc1O</smiles><smiles>Oc1ccc(O)c(Cl)c1</smiles><smiles>Oc1ccc(O)cc1</smiles><smiles>O=C(O)CC(=O)O</smiles><smiles>O=C(O)C(=O)O</smiles><smiles>O=C(O)O</smiles>

the electrodes studied. Moreover, all parameters follow the quadratic model. Generally, this method can be used as a pretreatment process for biological systems to remove the resistant organic compounds such as chlorophenoxy pesticides groups.

\section{Conflicts of interest}

There are no conflicts to declare.

\section{Acknowledgements}

This study has been adapted from a PhD student thesis at Hamadan University of Medical Sciences. The study was funded by deputy of research and technology, Hamadan University of Medical Sciences (No. 9611177276).

\section{References}

1 M. R. Samarghandi, M. Mohammadi, A. Karami, L. Tabandeh, A. Dargahi and F. Amirian, Pol. J. Environ. Stud., 2017, 26, 2189-2195.

2 M. Arias-Estévez, E. López-Periago, E. Martínez-Carballo, J. Simal-Gándara, J.-C. Mejuto and L. García-Río, Agric., Ecosyst. Environ., 2008, 123, 247-260.

3 J. R. de Lipthay, S. R. Sørensen and J. Aamand, Environ. Pollut., 2007, 148, 83-93.

4 R. Chidambaram, Ecol. Eng., 2016, 92, 97-105.

5 C. J. Burns and G. M. Swaen, Crit. Rev. Toxicol., 2012, 42, 768786.

6 M. Essandoh, D. Wolgemuth, C. U. Pittman Jr, D. Mohan and T. Mlsna, Chemosphere, 2017, 174, 49-57.

7 E. Seck, J. Doña-Rodríguez, C. Fernández-Rodríguez, O. González-Díaz, J. Araña and J. Pérez-Peña, Appl. Catal., $B, 2012,125,28-34$.

8 S. Sanchis, A. M. Polo, M. Tobajas, J. J. Rodriguez and A. F. Mohedano, Chemosphere, 2013, 93, 115-122.

9 C. Bradu, M. Magureanu and V. Parvulescu, J. Hazard. Mater., 2017, 336, 52-56.

10 S. Harris, K. Solomon and G. Stephenson, J. Environ. Sci. Health, Part B, 1992, 27, 23-38.

11 C. R. de Arcaute, S. Soloneski and M. Larramendy, Ecotoxicol. Environ. Saf., 2016, 128, 222-229.

12 S. M. Shallangwa, Agric. J., 2011, 6, 177-180.

13 K. H. H. Aziz, H. Miessner, S. Mueller, A. Mahyar, D. Kalass, D. Moeller, I. Khorshid and M. A. M. Rashid, J. Hazard. Mater., 2018, 343, 107-115.

14 M. Pirsaheb, A. Dargahi, S. Hazrati and M. Fazlzadehdavil, Desalin. Water Treat., 2014, 52, 4350-4355.

15 V. Njoku, M. A. Islam, M. Asif and B. Hameed, J. Environ. Manage., 2015, 154, 138-144.

16 J.-M. Fontmorin, S. Huguet, F. Fourcade, F. Geneste, D. Floner and A. Amrane, Chem. Eng. J., 2012, 195, 208-217.

17 S. González-Cuna, J. Galíndez-Mayer, N. Ruiz-Ordaz, S. Murugesan, A. Piña-Escobedo, J. García-Mena, E. LimaMartínez and F. Santoyo-Tepole, Int. Biodeterior. Biodegrad., 2016, 107, 123-131. 
18 X. Bian, J. Chen and R. Ji, Materials, 2013, 6, 1530-1542.

19 S. Pulkka, M. Martikainen, A. Bhatnagar and M. Sillanpää, Sep. Purif. Technol., 2014, 132, 252-271.

20 J. Li, W. Guan, X. Yan, Z. Wu and W. Shi, Catal. Lett., 2018, 148, 23-29.

21 C. Ramírez, A. Saldaña, B. Hernández, R. Acero, R. Guerra, S. Garcia-Segura, E. Brillas and J. M. Peralta-Hernández, J. Ind. Eng. Chem., 2013, 19, 571-579.

22 L. O. Conte, A. V. Schenone, B. N. Giménez and O. M. Alfano, J. Hazard. Mater., 2018, S0304-3894(18)30237-1.

23 M. Panizza and G. Cerisola, Chem. Rev., 2009, 109, 65416569.

24 C. Comninellis, Electrochim. Acta, 1994, 39, 1857-1862.

25 A. N. S. Rao and V. T. Venkatarangaiah, Environ. Sci. Pollut. Res., 2014, 21, 3197-3217.

26 X. Yu, M. Zhou, Y. Hu, K. G. Serrano and F. Yu, Environ. Sci. Pollut. Res., 2014, 21, 8417-8431.

27 F. Montilla, E. Morallon, A. De Battisti, A. Benedetti, H. Yamashita and J. Vazquez, J. Phys. Chem. B, 2004, 108, 5044-5050.

28 Y.-J. Shih, Y.-H. Huang and C. Huang, Electrochim. Acta, 2017, 257, 444-454.

29 R. M. Farinos and L. A. Ruotolo, Electrochim. Acta, 2017, 224, 32-39.

30 J. M. Aquino, M. A. Rodrigo, R. C. Rocha-Filho, C. Sáez and P. Cañizares, Chem. Eng. J., 2012, 184, 221-227.

31 J.-M. Fontmorin, J. Siguié, F. Fourcade, F. Geneste, D. Floner, I. Soutrel and A. Amrane, Sep. Purif. Technol., 2014, 132, 704711.

32 A. Ansari and D. Nematollahi, Water Res., 2018, 144, 462473.

33 Y.-s. Wang, F. Yang, Z.-h. Liu, L. Yuan and G. Li, Catal. Commun., 2015, 67, 49-53.

34 A. Dargahi, D. Nematollahi, G. Asgari, R. Shokoohi, A. Ansari and M. R. Samarghandi, RSC Adv., 2018, 8, 39256-39268.

35 A. Dargahi, M. Mohammadi, F. Amirian, A. Karami and A. Almasi, Desalin. Water Treat., 2017, 87, 199-208.

36 R. Shokoohi, A. J. Jafari, A. Dargahi and Z. Torkshavand, Desalin. Water Treat., 2017, 77, 256-263.

37 M. R. Samarghandi, D. Nemattollahi, G. Asgari, R. Shokoohi, A. Ansari and A. Dargahi, Sep. Sci. Technol., 2018, 1-16.

38 Q. Zhuo, Q. Xiang, H. Yi, Z. Zhang, B. Yang, K. Cui, X. Bing, Z. Xu, X. Liang and Q. Guo, J. Electroanal. Chem., 2017, 801, 235-243.
39 X. Hao, S. Dan, Z. Qian, Y. Honghui and W. Yan, RSC Adv., 2014, 4, 25011-25017.

40 R. A. de Souza and L. M. Ruotolo, Int. J. Electrochem. Sci., 2013, 8, 643-657.

41 N. Jaafarzadeh, F. Ghanbari and A. Zahedi, Journal of water process engineering, 2018, 22, 203-209.

42 L. Wang, F. Pan and L. Wang, Int. J. Electrochem. Sci., 2014, 9, 3628-3636.

43 Q. Dai, J. Zhou, M. Weng, X. Luo, D. Feng and J. Chen, Sep. Purif. Technol., 2016, 166, 109-116.

44 S. A. Neto and A. De Andrade, Electrochim. Acta, 2009, 54, 2039-2045.

45 S.-M. Hong, Z. W. Min, C. Mok, H.-y. Kwon, T.-k. Kim and D.-h. Kim, Food Sci. Biotechnol., 2013, 22, 1773-1778.

46 M. Kobya, E. Senturk and M. Bayramoglu, J. Hazard. Mater., 2006, 133, 172-176.

47 I. Yahiaoui, F. Aissani-Benissad, F. Fourcade and A. Amrane, Chem. Eng. J., 2013, 221, 418-425.

48 J. M. Aquino, R. C. Rocha-Filho, L. A. Ruotolo, N. Bocchi and S. R. Biaggio, Chem. Eng. J., 2014, 251, 138-145.

49 X. Li, H. Xu and W. Yan, RSC Adv., 2016, 6, 82024-82032.

50 F. C. Moreira, R. A. Boaventura, E. Brillas and V. J. Vilar, Appl. Catal., B, 2017, 202, 217-261.

51 A. Fischbacher, J. von Sonntag, C. von Sonntag and T. C. Schmidt, Environ. Sci. Technol., 2013, 47, 9959-9964.

52 A. R. Pipi, I. Sirés, A. R. De Andrade and E. Brillas, Chemosphere, 2014, 109, 49-55.

53 F. Souza, C. Saéz, M. R. Lanza, P. Cañizares and M. Rodrigo, Sep. Purif. Technol., 2015, 149, 24-30.

54 K. S. Hashim, A. Shaw, R. Al Khaddar, M. O. Pedrola and D. Phipps, J. Environ. Manage., 2017, 196, 224-233.

55 M. Kobya, E. Gengec and E. Demirbas, Chem. Eng. Process., 2016, 101, 87-100.

56 N. Jaafarzadeh, F. Ghanbari and M. Ahmadi, Chem. Eng. J., 2017, 320, 436-447.

57 S. Zourab, N. Abu Ghalwa, F. R. Zaggout, M. Y. Al-Asqalany and N. Khdear, J. Dispersion Sci. Technol., 2009, 30, 712-719.

58 N. A. Ghalwa, M. Hamada, H. M. A. Shawish and O. Shubair, Arabian J. Chem., 2016, 9, S821-S828.

59 Y. Feng, L. Yang, J. Liu and B. E. Logan, Environ. Sci.: Water Res. Technol., 2016, 2, 800-831.

60 I. Sirés, C. Low, C. Ponce-de-León and F. Walsh, Electrochem. Commun., 2010, 12, 70-74.

61 H. Liu, S. Yu, T. Shen, S. Tong and C. Ma, Sep. Purif. Technol., 2014, 132, 27-32. 